\title{
SALAM PEMBUKA
}

Globalisasi adalah suatu era dimana antara satu daerah dengan daerah lainnya atau satu negara dengan negara lainnya, tiada batas lagi, dari segi komunikasi, pasaran, maupun aspek lainnya (Jameson and Miyoshi [ed.], 1999: xi). Era global atau dikenal juga dengan era post industri merupakan representasi simbolik dari pergeseran ruang-waktu yang ada di dalam jagat raya yang di dalamnya terdapat berbagai peristiwa kehidupan yang berlangsung. Pergeseran tersebut adalah suatu realitas yang dapat diketahui melalui tanda-tanda pergeseran atau perubahan peristiwa, obyek, dan situs.

Globalisasi dengan segala kecenderungannya merupakan tantangan tersendiri bagi penyelengaraan pendidikan nasional. Ketiadaan batas antar negara (borderless) dan persaingan bebas mengindikasikan akan terjadinya suatu dialog sosial budaya antara negara dengan segala karakteristik dan kecenderungannya. Konteks inilah yang kemudian menjadikan pendidikan nasional menghajatkan dirinya pada suatu bentuk pendidikan kompetitif dalam persaingan global, juga mencerdaskan dan mendewasakan anak bangsa agar tetap eksis dengan karakteristik sosial dan budaya aslinya. Dalam UUSPN No. 20 Th 2003 dinyatakan, bahwa pendidikan nasional berfungsi mengembangkan kemampuan dan membentuk watak ser-ta peradaban bangsa yang bermartabat dalam rangka mencerdaskan kehidupan bangsa.

Dalam rangka merespon amanat UUSPN tersebut dan masalahmasalah nilai serta karakter anak bangsa yang memprihatinkan, akhirakhir ini kementerian pendidikan dan kebudayaan dan kementerian agama RI gencar mensosialisasikan pendidikan karakter di dalam sekolah/madrasah. Karakter adalah watak, tabiat, akhlak, atau kepribadian seseorang yang terbentuk dari hasil internalisasi berbagai 
kebajikan (virtues) yang diyakini dan digunakan sebagai landasan untuk cara pandang, berpikir, bersikap, dan bertindak. Kebajikan terdiri atas sejumlah nilai, moral, dan norma seperti; jujur, berani bertindak, dapat dipercaya, dan hormat kepada orang lain. Adapun pendidikan adalah suatu usaha yang sadar dan sistematis dalam mengembangkan potensi peserta didik. Pendidikan juga merupakan suatu usaha masyarakat dan bangsa dalam mempersiapkan generasi muda bagi keberlangsungan kehidupan dalam masyarakat dan bangsa yang lebih baik di masa depan. Keberlangsungan itu ditandai oleh pewarisan budaya dan karakter yang telah dimiliki masyarakat dan bangsa tersebut.

Pertanyaan penting yang perlu dicarikan jawabannya adalah bagaimana memberikan jaminan yang pasti agar pendidikan karakter dapat terimplementasi dengan baik dalam sekolah/madrasah. Implementasi pendidikan karakter tersebut diharapkan mampu mengatasi persoalan karakter bangsa. Terkait dengan itu, sebenarnya terdapat banyak variabel yang berkontribusi terhadap terwujudnya pelaksanaan pendidikan karakter dalam sekolah/madrasah. Salah satu variabel penting yang perlu mendapat perhatian adalah variabel manajemen pendidikan. Penelitian tentang efektifitas sekolah dan pengembangannya di beberapa negara mengindikasikan bahwa kualitas kepemimpinan dan manajemen merupakan variabel terpenting untuk menentukan sukses atau tidaknya suatu sekolah dalam mendidik anak didiknya. Manajemen yang baik akan memberikan kontribusi positif bagi kualitas sekolah (Bush, 2006: 3). Manajemen pendidikan berbicara tentang berbagai upaya pengelolaan yang dilakukan secara logis dan sistematis untuk mencapai tujuan pendidikan. Dalam konteks ini tentu saja yang menjadi salah satu tujuan pendidikan adalah terbentuknya karakter mulia dalam diri anak didik.

Atas dasar pemikiran di atas, maka NADWA Jurnal Pendidikan Islam dalam edisi ini mengusung sebuah tema tentang Manajemen Pendidikan Islam sebagai upaya menuju terbentuknya karakter mulia. Selamat membaca.[] 